\title{
Analysis of Contact Stresses of Theoretical and Worn Profile by Using Computer Simulation
}

Lukáš Smetanka, Pavol Št’astniak

Faculty of Mechanical Engineering, University of Zilina. Univerzitna 8215/1, 01008 Žilina. Slovak Republic. E-mail: lukas.smetanka@fstroj.uniza.sk,pavol.stastniak@fstroj.uniza.sk

The wear of rails and rail wheels is important problem in rail traffic. The change of the shape of the wheel profile has not only a great influence on the dynamic properties of the vehicle (like stability, safety by passing curved tracks, etc.), but also affects the ride comfort of passengers and environmental insults. In extreme cases it can cause rail derailment, which is unwanted status. For these and other reasons, great effort is brought to create a software, which would be capable to compute the wear of a rail wheel profile. The presented article demonstrates how the change of the rail profile influences the resulting contact stresses. The wheel and rail geometries were created by using the CAD software CATIA. For the creation of the rail profile, the PYTHON programming language was used, because the imported .step file caused inaccuracies during import. The contact stresses were computed by using the commercial FEM software ABAQUS, and the results were compared with other methods which are used to calculate contact stresses.

Keywords: contact stress, wheel and rail wear, computer simulation

\section{Acknowledgement}

This paper was created during the processing of the project "RAILBCOT - RAIL Vehicles Brake Components Test Stand", ITMS Code 26220220011 based on the support of Research and Development Operational Program financed by European Fund of a Regional Development. The work was also supported by the project No. APVV-0842-11: “Equivalent railway operation load simulator on the roller rig".

\section{References}

[1] ARGATOV, I. I., FADIN, Y. A. (2008). Mathematical Modeling of the Periodic Wear Process in Elastic Contact between Two Bodies. In Journal of Friction and Wear. ISSN: 1068-3666, 2008, vol. 29, No. 2, p. 81-85.

[2] BARBINTA, C. I. et al. (2014). Wheel-rail contact modelling and analysis, considering profiles types and lateral displacement. In Transport Research Arena: 5th Conference: Transport Solutions from Research to Deployment. Paris: 14.04.2014 - 17.04.2014. France: Paris. Accession Number: 01540797.

[3] DIŽO, J., BLATNICKÝ, M. (2016). Use of multibody systém dynamics as a tool for rail vehicle behavior diagnostics. In Diagnostika. ISSN: 1641-6414, 2016, vol. 17, No. 2, p. 9-16.

[4] EKBERG, A., ÅKESSON, B., KABO, E. (2014). Wheel/rail rolling contact fatigue - Probe, predict, prevent. In Wear. ISSN: 0043-1648, 2014, vol. 314, p. 2-12.

[5] HARUŠINEC, J. (2010). Napät’ová analýza kontaktu kolesa a kol'ajnice ako vstup pre predikciu opotrebenia: dizertačná práca. Žilina: Žilinská Univerzita v Žiline. 2010. 149 s.

[6] GERLICI, J., LACK, T. (2004). Kontakt železničného dvojkolesia a kol'aje: Žilina: Žilinská univerzita v Žiline, EDIS, 2004. 200 s. ISBN 80-710000-317-5

[7] GERLICI, J., LACK, T., HARUŠINEC, J. (2013). The test stand load modulus implementation for the realistic railway operation in the laboratory conditions In: Manufacturing technology: Journal for science, research and production. ISSN 1213-2489. - Vol. 13, no. 4 (2013), (pp. 444-449)

[8] JANDORA, R. (2012). Výpočtové modelování dynamických projevů v kontaktu kola a kolejnice s obecnou geometrií kontaktních povrchů: dizertačná práca. Brno: Vysoké Učení Technické v Brně. 2012. $156 \mathrm{~s}$.

[9] LACK, T., GERLICI, J. (2013). The FASTSIM method modification in speed up the calculation of tangential contact stresses between wheel and rail. In: Manufacturing technology: Journal for science, research and production. ISSN 1213-2489. - Vol. 13, no. 4 (2013), (pp. 486-492).

[10] LACK, T., GERLICI, J. (2005). Contact area and normal stress determination on railway wheel / rail contact. In: Communications - scientific letters of the University of Žilina. ISSN 1335-4205. - Vol. 7, No. 2 (2005), (pp. 3845).

[11] PAERCE, T.G., SHERRAT, N. D. (1991). Prediction of wheel profile wear. In Wear. ISSN: 0043-1648, 1991, vol. 144, p.343-351 
[12] PELAGIĆ, Z., NÁGEL', M., ŽMINDÁK, M., RIECKY, D. (2015). Wear simulation modeling by using the finite element method In: Manufacturing technology: Journal for science, research and production. ISSN 1213-2489. Vol. 15, no. 2 (2015), (pp. 191-195).

[13] RUZICKA, L., MADL, J. (2012). The importance of measured values number in evaluating the wear size of inserts In: Manufacturing technology: Journal for science, research and production. ISSN 1213-2489. - Vol. 12, no. 13 (2012), (pp. 227-232).

[14] SVOBODA, M., SOUKUP, J. (2013). Dynamic Measurement of Four-Axle Railway Wagon In: Manufacturing technology: Journal for science, research and production. ISSN 1213-2489. - Vol. 13, no. 4 (2013), (pp. 552$558)$.

[15] ZHU, Y. (2013). Adhesion in the wheel-rail contact: Doctoral thesis. Stockholm: Royal Institute of Technology. 2013. 44 p.

Paper number: M2017105

Copyright (C) 2017. Published by Manufacturing Technology. All rights reserved. 